A C T A C H E M I CA S C A N D I NA V I C A 10 (1956) $20-25$

\title{
Enzymatic Formation of Nitrous Oxide from Nitrite
}

\author{
T. YAMADA* and ARTTURI I. VIRTANEN \\ Laboratory of the Foundation for Chemical Research, Biochemical Institute, \\ Helsinki, Finland
}

\begin{abstract}
A halotolerant Micrococcus strain evolved gas from nitrite (and nitrate) by reduction. Both dried cell preparations and a cell-free enzyme solution prepared from the organism was used in the experiments. The predominant product of the reduction was nitrous oxide. Nitrogen could not be established with certainty in the gas evolved. Practically no reduction of nitrite to hydroxylamine could be detected.
\end{abstract}

Geveral authors have observed the formation of nitrous oxide in experiments $N_{\text {with denitrifying bacteria. Beijerinck and Minkman }}{ }^{1}$ and Kluyver and Verhoeven $^{2}$ succeeded to accumulate nitrous oxide in the gaseous products by using a higher concentration of nitrate and "vacuum experiments", respectively. 'The main product of the gas evolved by denitrifying bacteria under ordinary conditions was, however, nitrogen. Sacks and Barker ${ }^{3}$ and Allen and van $\mathrm{Niel}^{4}$ rejected the possibility that nitrous oxide might be a normal intermediate in denitrification. In their remarkable work Kluyver and Verhoeven are, on the other hand, of the opinion that molecular nitrogen is formed through reduction of nitrous oxide even if it is very probable that a part of the nitrogen can be formed also directly from the precursor of nitrous oxide.

The stepwise assimilatory reduction of nitrate to ammonia differs from denitrification on the stage between nitrite and hydroxylamine (cf. below). The original aim of the present investigation was to obtain further knowledge about the hitherto obscure reduction of nitrite to hydroxylamine, i. e. a reaction stage belonging to the assimilatory nitrate reduction. For this purpose we used both a dry cell preparation and a cell-free enzyme solution from the same halotolerant Micrococcus which Egami et al..$^{5}$ had used when establishing that specific nitrate reductase, nitrite reductase and hydroxylamine reductase act successively in assimilatory nitrate reduction which leads to ammonia. In our experiments even living cells of Micrococcus did not reduce nitrate and nitrite to ammonia but formed practically only gaseous products. This was also the case both with our dry cell preparations and cell-free enzyme

* Fellowship from the Travelling Fund of the Ministry of Education of Japan. 
Fig. 1. Gas evolution in experiments with dried cells. Main chamber: $1 \mathrm{ml}$ bacterial suspension ( $20 \mathrm{mg} / \mathrm{ml}$ ), $0.5 \mathrm{ml} \mathrm{1/2} \mathrm{M}$ phosphate buffer ( $p H$ 6.8), $0.1 \mathrm{ml}$ methylene blue solution 0.01 M. Side arm: $0.5 \mathrm{ml} 0.02$ $\mathrm{MNO} \mathrm{NO}_{-}^{-}$or $\mathrm{NO}_{\mathrm{a}}^{-}$solution added into the main chamber after $3^{2} 0$ min. preincubation. Temp. $35^{\circ} \mathrm{C}$. O-O $\mathrm{NO}_{2}^{-}, \mathrm{NO} \mathrm{NO}_{3}^{-}$.

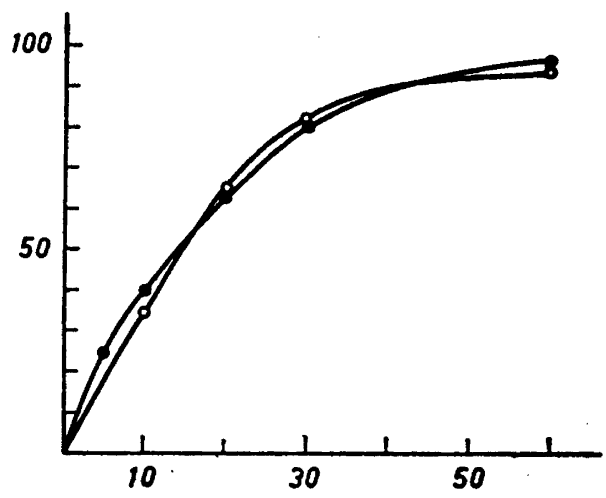

solutions. Our investigations came thus to be directed on the formation of nitrous oxide from nitrite.

Robinson et al. ${ }^{6}$ using Micrococcus halodenitrificans and Najjar and Allen 7 using Pseudomonas stutzeri and Bacillus subtilis obtained cell-free enzyme systems which evolved gas from nitrite. In the former case the gas was suggested to be nitrogen and also in the latter case the predominant product was nitrogen (with smaller amounts of nitric oxide and nitrous oxide).

\section{EXPERIMENTAL}

Cultivation of Micrococcus and preparation of dried cells. The test organism was a strain of Micrococcus, isolated in the laboratory of Japan Marine Product Co., named tentatively halotolerant bacteria No. 203. The cultural medium was peptone broth containing $10 \%$ of $\mathrm{NaCl}$ and $3 \%$ of $\mathrm{KNO}_{3}$. The cells harvested from 36-48 hours . liquid cultures were washed several times with $10 \% \mathrm{NaCl}$ solution and lyophilized.

Preparation of enzyme solution. The dried cell suspension $(2 \mathrm{~g} / 80 \mathrm{ml})$ which had been dialysed overnight against diluted phosphate buffer, $\mathrm{pH} 6.8$, was centrifuged at $0^{\circ} \mathrm{C}$

Table 1. Gas evolution from nitrite by dried cells.

\begin{tabular}{|c|c|c|c|c|}
\hline \multirow{3}{*}{$\begin{array}{c}\begin{array}{c}\text { Total volume } \\
\text { of } \\
\text { reaction mixture }\end{array} \\
\mathrm{ml}\end{array}$} & \multicolumn{4}{|c|}{$\begin{array}{l}\text { Volume of gas evolved } \\
\text { if calculated as }\end{array}$} \\
\hline & \multicolumn{2}{|c|}{$\mathrm{N}_{2}$} & \multicolumn{2}{|c|}{$\mathrm{N}_{2} \mathrm{O}$} \\
\hline & $\mu \mathrm{l}$ & $10^{-5} \mathrm{M}$ & $\mu \mathrm{l}$ & $10^{-5} \mathrm{M}$ \\
\hline $\begin{array}{l}3.0 \\
6.0 \\
9.0\end{array}$ & $\begin{array}{l}92 \\
80 \\
61\end{array}$ & $\begin{array}{l}0.81 \\
0.71 \\
0.54\end{array}$ & $\begin{array}{l}102 \\
105 \\
104\end{array}$ & $\begin{array}{l}0.91 \\
0.93 \\
0.93\end{array}$ \\
\hline
\end{tabular}

Main chamber: $1 \mathrm{ml}$ bacterial suspension $(20 \mathrm{mg} / \mathrm{ml}), 0.5 \mathrm{ml} \mathrm{l} / 2 \mathrm{M}$ phosphate buffer (pH 6.8), $0.1 \mathrm{ml} \mathrm{0.01} \mathrm{M}$ methylene blue solution, appropriate amount of water.

Side arm: $0.5 \mathrm{ml} \mathrm{0.02} \mathrm{M}$ NaNO, solution added into the main chamber after $30 \mathrm{~min}$. preincubation.

Acta Chem. Scand. 10 (1956) No. 1 
Table 2. The mass spectrometrical data of the gas evolved.

\begin{tabular}{|c|c|c|c|c|}
\hline \multirow[b]{3}{*}{ Mass : } & \multicolumn{4}{|c|}{ Voltage observed on each peak } \\
\hline & \multicolumn{2}{|c|}{ without $\mathrm{NO}_{2}^{-}$} & \multicolumn{2}{|c|}{ with $\mathrm{NO}_{2}^{-}$} \\
\hline & Expt. 1 & Expt. 2 & Expt. 1 & Expt. 2 \\
\hline $\begin{array}{ll}28 & \left(\mathrm{~N}_{2}\right) \\
30 & (\mathrm{NO}) \\
40 & (\mathrm{Ar}) \\
44 & \left(\mathrm{~N}_{2} \mathrm{O}\right)\end{array}$ & $\begin{array}{l}1.13 \\
0.06 \\
0.032 \\
0.127\end{array}$ & $\begin{array}{l}2.33 \\
0.03 \\
0.060 \\
0.076\end{array}$ & $\begin{array}{l}1.43 \\
0.320 \\
0.039 \\
1.17\end{array}$ & $\begin{array}{l}1.42 \\
0.240 * \\
0.038 \\
0.950\end{array}$ \\
\hline
\end{tabular}

for $30 \mathrm{~min}$. at $15000 \times \mathrm{g}$. From the supernatant thus obtained the active protein was precipitated by potassium citrate between half and full saturation. The precipitate was resolved into $20 \mathrm{ml}$ of distilled water and used as enzyme solution.

Measurement of gas evolution. The conventional Warburg apparatus was used. The gas phase was nitrogen unless otherwise mentioned. The dried cells maintained a rather strong activity of formic dehydrogenase, and formate was therefore used as hydrogen donor in the following experiments with dried cells. Methylene blue was added as intermediate hydrogen carrier to make the reaction rapid enough. The dehydrogenase activity of the cell-free enzyme solution was not strong enough and therefore leuco-methylene blue produced from methylene blue by hydrogen in the presence of palladium black carried on BaSO, was used as hydrogen donor in experiments with enzyme solution. Hydroxylamine was estimated according to the method of $\mathrm{Csaky}^{8}$, ammonia to that of Conway ${ }^{\circ}$.

\section{RESULTS}

In the present experiments with the halotolerant Micrococcus No. 203 the dried cells reduced nitrate to nitrite, and hydroxylamine to ammonia almost quantitatively, while on the other hand practically no, or possibly only a very weak, reduction of nitrite to hydroxylamine and ammonia could be detected. The principal end products of nitrite reduction were gaseous (Fig. 1).

The gas evolved was identified as follows. Because it was reasonable to suppose that the gaseous reduction product of nitrite would be nitrogen or/and nitrous oxide the solubility of the gas evolved was estimated. Table 1 shows the volumes of gas when the volume of the liquid phase in Warburg flasks was varied by addition of water. The values calculated as pure nitrogen or nitrous oxide suggest that the gas should be practically exclusively nitrous oxide.

By a mass spectrometric method Dr. Burris in the laboratory of the Department of Biochemistry, University of Wisconsin, kindly analysed the gas samples which were collected from Warburg flasks and sent to him. The gas phase was in these experiments hydrogen. The analytical data are presented in Table 2. The great differences between experiments with and without nitrite were observed at mass 30 and 44. The former peak corresponded de-

* Because a peak of about $1 / 5$ the height of the $\mathrm{N}_{2} \mathrm{O}$ peak is obtained as a NO peak arising from the cleavage of $\mathrm{N}_{2} \mathrm{O}$ in the instrument the gas mixture contained practically no NO. 
Fig. 2. Gas evolution in experiments with cell-free enzyme solution. Main chamber: 1 ml enzyme solution, $2 \mathrm{ml} 1 / 2 \mathrm{M}$ phosphate buffer ( $p H$ 6.8), 3 ml leuco-methylene blue solution. Side arm: $0.5 \mathrm{ml} 0.02 \mathrm{M} \mathrm{NO}_{\mathrm{s}}^{-}$or $\mathrm{NO}^{-}$solution added into the main chamber after 30 min. preincubation. Temp. $35^{\circ} \mathrm{C}$. $\mathrm{O}-\mathrm{O} \mathrm{NO}_{2}^{-}, \mathrm{NO} \mathrm{NO}_{8}^{-}$

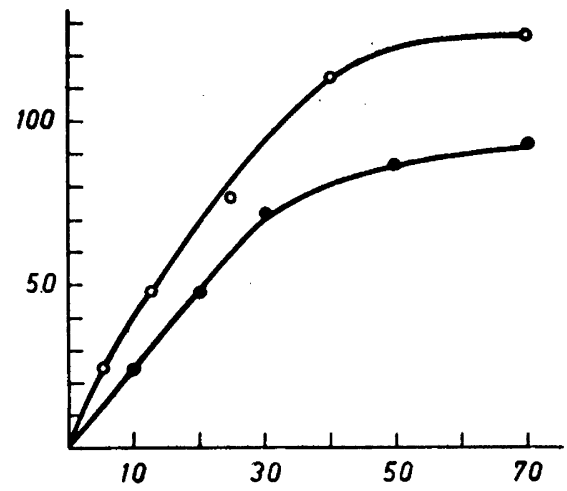

finitely to nitric oxide. Although the latter could correspond both to carbon dioxide and nitrous oxide the possibility of carbon dioxide was excluded because the flasks contained $\mathrm{KOH}$ in the center wells. There was another peak at mass 28 corresponding to nitrogen but this probably was due to air contamination because a mass 40 peak for argon also was evident. There is, moreover, a considerable cleavage of nitrous oxide to nitric oxide in the mass spectrometer. A peak of about $1 / 5$ the height of the parent nitrous oxide peak is obtained as a nitric oxide peak arising from the cleavage of nitrous oxide in the instrument. Thus a good share of the mass 30 peak could have arisen from nitrous oxide. Therefore, it may be concluded that the predominant product in the present experiments also on the basis of the mass spectrometric analysis was nitrous oxide.

The gas evolution from nitrite and nitrate even in experiments with cellfree enzyme preparation was strong, and no noticeable amounts of hydroxyl-

Table 3. Reduction of nitrite and hydroxylamine by cell-free enzyme solution and formation of hydroxylamine and ammonia.

\begin{tabular}{|l|c|c|c|}
\hline \multirow{2}{*}{ Substrate } & Substrate reduced & \multicolumn{2}{|c|}{ Reduction products (gaseous not estimated) } \\
\cline { 2 - 4 } & $10^{-6} \mathrm{~mole}$ & $\begin{array}{c}\mathrm{NH}_{2} \mathrm{OH} \\
10^{-6} \mathrm{~mole}\end{array}$ & $\begin{array}{c}\mathrm{NH}_{3} \\
10^{-6} \mathrm{~mole}\end{array}$ \\
\hline $\mathrm{NaNO}_{2}$ & 7.5 & $0.5 ?^{*}$ & 0.2 \\
$\mathrm{NH}_{2} \mathrm{OH}$ & 6.9 & - & 4.9 \\
\hline
\end{tabular}

Thunberg tubes were used. The contents were as follows: $1 \mathrm{ml}$ enzyme solution, $2 \mathrm{ml} \mathrm{0.5} \mathrm{M} \mathrm{phosphate} \mathrm{buffer} \mathrm{(} \mathrm{pH}$ 6.8), leuco-methylene blue solution $3 \mathrm{ml}$ for $\mathrm{NO}_{2}^{-}$and $2 \mathrm{ml}$ for $\mathrm{NH}_{2} \mathrm{OH}$. Reaction time $1 \mathrm{~h}$.

* After treatment with urea no hydroxylamine could be found. The presence of hydroxylamine is therefore not probable.

Acta Chem. Scand. 10 (1956) No. 1 
amine or ammonia were detected as shown in Fig. 2 and Table 3. In the experiment presented in Fig. 2 no nitrite could be found in the solution at the end of the experiment and also no hydroxylamine.

\section{DISCUSSION}

In our experiments the predominant product of nitrite reduction with halotolerant Micrococcus has been nitrous oxide, not only with dried cells but also in a system which consisted of cell-free enzyme solution, nitrite and leucomethylene blue. The results suggest that the reaction might proceed according to the following scheme:

$$
2 \mathrm{HNO}_{3} \rightarrow 2 \mathrm{HNO}_{2} \rightarrow 2(=\mathrm{NOH}) \rightarrow \mathrm{N}_{2} \mathrm{O}
$$

In the same halotolerant micro-organism, used in the present work, Egami et al. have established the specific nitrate, nitrite and hydroxylamine reductases. They have thus corroborated the conception that assimilatory nitrate reduction proceeds via the following reaction stages:

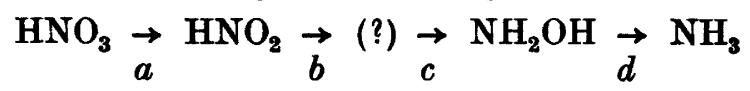

In our experiments with dried cells as well as with cell-free enzyme solution the reactions $a$ and $d$ could be realized almost quantitatively. On the other hand nitrite was not reduced to hydroxylamine (and of course not to ammonia either) at least not in amounts which could be established with certainty. As the reduction product of nitrite practically only nitrous oxide was formed. Nitrogen could not be established in the gas mixture, not with certainty anyhow. Reaction stage $c$ was accordingly inhibited under our reaction conditions and the reduction of nitrite was on account of this dissimilatory, nitrous acid being the only reaction product which could be established with certainty. It is difficult to understand why reaction $c$ was lacking in our experiments although Egami et al. succeeded in reducing nitrite to hydroxylamine with the same bacteria. The only explanation is that the bacteria in our experiments for some unknown reason were lacking in the enzyme which catalyses reaction $c$.

The radical $=\mathrm{NOH}$ is the logical first reduction product of nitrite. It can be assumed that one molecule of water is split off under formation of one molecule of nitrous oxide when two radicals combine with each other: $2(=\mathrm{NOH}) \rightarrow \mathrm{N}_{2} \mathrm{O}+\mathrm{H}_{2} \mathrm{O}$. When discussing possible precursors of nitrous oxide or molecular nitrogen, respectively, formed in denitrification Kluyver and Verhoeven have fixed their attention on imido-nitric acid, $H N=N=0$, for

which the wrong name "nitramide" has generally been used. They found that this compound rapidly and spontaneously decomposes into nitrous oxide and water at $\mathrm{pH}$ ranges where denitrification takes place. There is accordingly an experimental basis for the concept that this compound could be formed in denitrification and should thus be the long sought precursor of nitrous oxide. As Kluyver points out its formation is, however, obscure. He proposes tentatively the following mechanism 


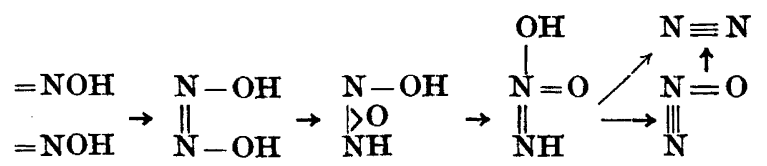

The concept about the formation of nitrous oxide from the radical $=\mathrm{NOH}$ via a simpler mechanism (cf. above) is tempting.

When taking into consideration the observations made by Egami et al. about the reduction of nitrite to hydroxylamine and our results concerning the formation of nitrous oxide as the only with certainty established reduction product of nitrite the following pathway can be proposed for assimilatory and dissimilatory nitrate reduction with the Micrococcus in question

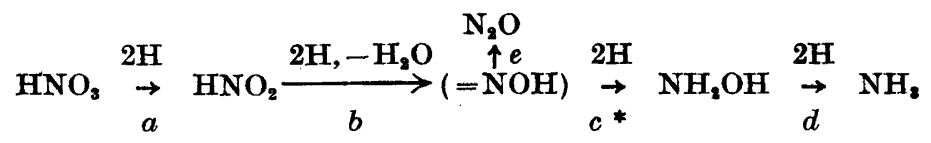

Reaction stages $a, b, c$, and $d$ are enzymatic, $e$ at least partly spontaneous.

According to this idea the assimilatory nitrate reduction differs from denitrification because of lack of the enzyme which reduces the intermediate between nitrite and hydroxylamine. Thus bacteria causing denitrification could be formed via mutation from bacteria which reduce nitrate to ammonia and use it as their nitrogen source.

The authors are greatly indebted to Dr. R. H. Burris for his advice and his kindness in performing the mass spectrometric analyses.

\section{REFERENCES}

1. Beijerinck, M. W. and Minkman, D. C. Centr. Bakteriol. Parasitenk. II 25 (1910) 30.

2. Kluyver, A. J. and Verhoeven, W. Antonie van Leeuwenhoek J. Microbiol. Serol. 20 (1954) 241; Verhoeven, W. Aerobic sporeforming nitrate reducing bacteria (Diss.) Delft 1952.

3. Sacks, L. E. and Barker, H. A. J. Bacteriol. 64 (1952) 247.

4. Allen, M. B. and van Niel, C. B. J. Bacteriol. 64 (1952) 397.

5. Egami, F., Yamada, T. and Taniguchi, S. IIe Congrès international de biochimie, Paris, 21-27 Juillet 1952, M. Declume, Lons-le-Saunier, 1952; Taniguchi, S., Mitsui, H., Nakamura, K. and Egami, F. Ann. Acad. Sci. Fennicoe II Chem. 60 (1955) 200, ("Biochemistry of Nitrogen").

6. Robinson, J., Gibbons, N. E. and Thatcher, F. S. J. Bacteriol. 64 (1952) 69.

7. Najjar, V. A. and Allen, M. B. J. Biol. Chem. 206 (1954) 209.

8. Csàky, T. Z. Acta Chem. Scand. 2 (1948) 450.

9. Conway, E. J. Microdiffusion analysis and volumetric error, Crosby Lockwood \& Son Ltd., London 1947.

* Enzyme lacking in our experiments

Received October 1, 1955. 